\title{
STRATEGI KEPALA SEKOLAH DALAM MENINGKATKAN KUALITAS SEKOLAH MELALUI PEMENUHAN RUANG KELAS YANG MEMADAI
}

\author{
B. Zuroidatul Mahmudiyah \\ Achmad Supriyanto \\ Agus Timan \\ Universitas Negeri Malang \\ zuroidatul.mahmudiyah@gmail.com
}

\begin{abstract}
This study aims to find problems in improving the quality of schools and find strategies that can be done by principals in improving the quality of schools through the fulfillment of adequate classrooms. This study uses a qualitative method. Data is collected by observation, interviews, and documentation. Data were analyzed using qualitative descriptive. The results of his research, namely (1) problems in improving school quality, namely the lack of adequate classrooms and (2) strategies that can be carried out by principals in improving school quality through the fulfillment of adequate classrooms include: (a) inviting parents students to come to school aim to socialize (explain the problems that exist in the school regarding the lack of classrooms and the need to fulfill adequate classrooms and plans for the construction of adequate classrooms) and (2) establish partnerships with industry or private companies.
\end{abstract}

Keywords: the principal's strategy, school quality, fulfillment of the classroom

Abstrak: Penelitian ini bertujuan untuk mencari permasalahan dalam meningkatkan kualitas sekolah dan menemukan strategi yang dapat dilakukan oleh kepala sekolah dalam meningkatkan kualitas sekolah melalui pemenuhan ruang kelas yang memadai. Penelitian ini menggunakan metode kualitatif. Data dikumpulkan dengan cara observasi, wawancara, dan dokumentasi. Data dianalisis menggunakan deskriptif kualitatif. Hasil penelitiannya, yaitu (1) permasalahan dalam meningkatkan kualitas sekolah, yaitu kurangnya ruang kelas yang memadai dan (2) strategi yang dapat dilakukan oleh kepala sekolah dalam meningkatkan kualitas sekolah melalui pemenuhan ruang kelas yang memadai antara lain: (a) mengundang orang tua peserta didik untuk datang ke sekolah tujuannya untuk melakukan sosialisasi (menjelaskan permasalahan yang ada di sekolah mengenai kurangnya ruang kelas dan perlunya pemenuhan ruang kelas yang memadai serta rencana untuk pembangunan ruang kelas yang memadai) dan (2) menjalin kemitraan dengan industri atau perusahaan swasta.

Kata Kunci: strategi kepala sekolah, kualitas sekolah, pemenuhan ruang kelas

Sarana prasarana adalah hal yang sangat penting dalam menunjang kelancaran proses belajar mengajar. Kaitannya dengan pendidikan, sarana prasarana sangat dibutuhkan oleh guru maupun peserta didik dalam kegiatan belajar mengajar. Penyediaan dan pengelolaan sarana dan prasarana merupakan hal yang sangat penting karena dengan adanya penyediaan dan pengelolaan sarana prasarana yang ada di sekolah akan terpelihara dan jelas kegunaannya. Dalam hal penyediaan dan pengelolaan, pihak sekolah haruslah bertanggungjawab terhadap sarana prasarana terutama kepala sekolah yang langsung menangani hal tersebut. Pihak sekolah selain kepala sekolah pun juga harus memelihara dan memperhatikan sarana prasarana yang sudah ada. Maka dengan penyediaan sarana prasarana yang memadai, peserta didik bisa belajar dengan maksimal dan efisien.

Kepala sekolah memiliki peran dan tanggungjawab dan juga harus memastikan bahwa gaya administratifnya 
sejalan dengan tujuan yang akan dicapai oleh sekolah (Fasasi \& Oyeniran, 2014). Kepala sekolah dalam meningkatkan mutu sekolah perlu memperhatikan hal-hal yang berkaitan dengan kemajuan sekolah (Ekosiswoyo, 2007), yaitu salah satunya sarana dan prasarana yang menunjang proses belajar mengajar di sekolah.

Dalam suatu lembaga pendidikan, kepala sekolah memiliki peran yang sangat penting dan menentukan baik atau buruknya mutu sekolah. Oleh karena itu, kepala sekolah memiliki peran dalam mengembangkan sekolah. Misalnya, melalui penyediaan sarana yang memadai untuk meningkatkan mutu sekolah.

Kepemimpinan kepala sekolah sangat penting untuk efektivitas dan kinerja sekolah di semua tingkatan, oleh karena itu kepala sekolah harus memiliki dan mengembangkan strategi yang dapat memotivasi untuk perubahan kebijakan yang tepat (Cheng, 1994 dalam (Wang, 2018)). Untuk meningkatkan mutu sekolah, kepala sekolah haruslah memiliki strategi melalui penyediaan sarana yang memadai. Salah satu strateginya, yaitu mencari dan mengelola dana dari pemerintah untuk pembangunan sarana yang dianggap kurang memadai guna proses belajar mengajar yang maksimal. Menurut(Alimi, 2012), dalam penyediaan sarana belajar tidak hanya pemerintah saja yang turun tangan, tetapi juga dari organisasi perusahaan atau individu untuk menyumbang dalam bentuk uang dan barang untuk penyediaan sarana belajar. Apabila sarana yang memadai sudah tersedia, sarana tersebut haruslah dipelihara. Pemeliharaan sarana atau fasilitas sekolah merupakan salah satu program sekolah dalam rencana pengembangan sekolah. Hal ini sesuai dengan pendapat (Xaba, 2012), yang menyatakan bahwa pemeliharaan fasilitas sekolah merupakan program sekolah yang telah disusun dalam rencana pengembangan sekolah, jadi pemeliharaan fasilitas dianggap sebagai pengungkit strategis utama dalam proses perencanaan pembangunan sekolah.
Penelitian ini merupakan penelitian kualitatif. Dalam penelitian ini, data yang dikumpulkan bukan angka tapi berupa kata-kata atau gambaran. Data yang dimaksud dalam penelitian ini berasal dari observasi, wawancaran, dan dokumentasi. Oleh karena itu, dalam penelitian ini pendekatan yang digunakan adalah pendekatan deskriptif. Observasi dilakukan untuk mengamati kondisi di lapangan yang sebenarnya. Wawancara dilakukan dengan kepala sekolah dan disertai dengan dokumentasi yang relevan. Teknik analisis deskriptif kualitatif digunakan untuk menggambarkan kondisi yang ada di lapangan sesuai observasi yang telah dilakukan, hasil wawancara dengan kepala sekolah, dan dokumentasi yang relevan.

Teknik analisis data dalam penelitian ini menggunakan model Miles dan Huberman dalam (Sugiyono, 2010), antara lain (1) reduksi data, (2) penyajian data, dan (3) penarikan kesimpulan atau verifikasi. Langkahnya, yaitu pertamatama data yang diperoleh di lapangan dicatat dan dirinci kemudian dirangkum, dipilih hal-hal pokok, difokuskan pada halhal yang penting, dan membuang yang tidak perlu. Kemudian dilakukan penyajian data, yaitu menyampaikan informasi berdasarkan data yang diperoleh dan disusun dalam naratif. Adanya penyajian data memudahkan peneliti untuk memahami berbagai hal yang terjadi dan memungkinkannya untuk penarikan kesimpulan serta memberi tindakan yang seharusnya dilakukan.

\section{HASIL DAN PEMBAHASAN Permasalahan dalam Meningkatkan Kualitas Sekolah}

SMK Graha Madina Singosari merupakan salah satu sekolah swasta yang berada di Kabupaten Malang. Sekolah ini masih tergolong baru, karena baru berdiri tahun 2015. Sekolah ini berada dibawah naungan Yayasan Bani Syafii Singosari. Ada 4 (empat) program keahlian, yaitu teknik otomotif, teknik komputer dan informatika, manajemen perkantoran, dan akuntansi dan keuangan. Berdasarkan keputusan BAN S/M Provinsi Jawa Timur pada tahun

\section{METODE}


2018, dinyatakan bahwa SMK Graha Madina Singosari terakreditasi B (baik) dengan nilai 81 . Adapun rincian nilai akreditasi yang ada dalam 8 komponen, yaitu (1) standar isi: 93, (2) standar proses: 95, (3) standar kompetensi lulusan: 82), (4) standar pendidik dan tenaga kependidikan: 84 , (5) standar sarana prasarana: $72,(6)$ standar pengelolaan: $88,(7)$ standar pembiayaan: 79 , dan (8) standar penilaian pendidikan: 86.

Berdasarkan rincian nilai akreditasi yang ada dalam 8 (delapan) komponen tersebut, dapat diketahui bahwa nilai yang paling rendah adalah komponen standar sarana prasarana, yaitu 72. Setelah melakukan observasi di lapangan, sarana yang ada di sekolah tersebut kurang memadai. Yang paling terlihat dan yang menjadi masalah adalah kurangnya ketersediaan ruang kelas yang digunakan untuk proses belajar mengajar dan ada ruang kelas yang kurang layak untuk digunakan.

SMK Graha Madina Singosari memiliki 12 (dua belas) rombongan belajar, otomatis membutuhkan 12 (dua belas) ruang kelas juga untuk proses belajar mengajar. Bedasarkan pengamatan langsung dan hasil wawancara dengan kepala sekolah, di sekolah tersebut hanya ada 3 (tiga) ruang kelas. Namun, ada usaha dari pihak sekolah untuk menangani permasalahan kurangnya ruang kelas tersebut, yaitu (1) ada satu ruang yang digunakan untuk 3 (tiga) ruang kelas tanpa sekat, (2) aula sekolah digunakan untuk 3 (tiga) ruang kelas tanpa sekat, dan (3) meminjam 4 (empat) ruangan di TK yang satu yayasan untuk proses belajar mengajar.

Berdasarkan penjelasan kepala sekolah mengenai penanganan permasalahan kurangnya ruang kelas sebagai sarana belajar mengajar tersebut, tentunya akan ada dampak yang terjadi. Dampak utama yang akan terjadi, yaitu proses belajar mengajar tidak maksimal (Darmastuti \& Karwanto, 2014), dikarenakan baik guru maupun peserta didik merasa tidak nyaman. Terutama untuk ruangan yang dibagi atau digunakan menjadi 3 (tiga) ruang kelas tanpa sekat, tentunya akan mengganggu konsentrasi guru dalam menyampaikan materi pelajaran dan peserta didik pun juga akan terganggu dalam penerimaan materi pelajarannya.

\section{Upaya Kepala Sekolah dalam Meningkatkan Kualitas Sekolah}

Meningkatnya kualitas sekolah tidak akan tercapai apabila tidak didukung dengan sarana yang memadai. Oleh karena itu, usaha untuk pemenuhan ruang kelas yang memadai adalah salah satu hal yang harus senantiasa ditingkatkan terus menerus. Dalam hal ini, kepala sekolah SMK Graha Madina perlu strategi untuk meningkatkan kualitas sekolah melalui pemenuhan ruang kelas yang memadai demi kelancaran proses belajar mengajar (Muh. Fitrah, 2017).

Menurut (Suhardan, 2010), dalam meningkatkan mutu pembelajaran, kepala sekolah harus menyediakan fasilitas untuk mendukung kelancaran belajar mengajar yang memadai. Untuk meningkatkan profesionalisme guru, kepala sekolah harus memberikan perhatian berupa kemampuan yang baik dalam hal mengelola kelas (Cahyana, 2010), penyediaan sarana prasarana (Patterson, 2008). Jadi, dapat disimpulkan bahwa penyediaan sarana prasarana sebagai alat bantu mengajar merupakan tanggungjawab kepala sekolah.

Ada beberapa upaya yang telah dilakukan oleh kepala sekolah untuk meningkatkan kualitas sekolah melalui pemenuhan ruang kelas yang memadai, yaitu (1) kepala sekolah mencari dan mengelola dana bantuan dari pemerintah, (2) kepala sekolah mencari bantuan dari pihak yayasan baik berupa dana maupun sumbangan pemikiran atau ide mengenai rencana pembangunan sekolah untuk kedepannya, dan (3) bekerja sama dengan DU/DI.

\section{KESIMPULAN}

Pemenuhan ruang kelas yang memadai merupakan hal yang penting dalam meningkatan kualitas sekolah. Oleh karena itu, kepala sekolah harus memiliki strategi untuk meningkatkan kualitas sekolah, yaitu salah satunya melalui pemenuhan ruang kelas yang memadai guna berlangsungnya proses belajar 
mengajar yang maksimal. Permasalahan yang terjadi di SMK Graha Madina Singosari, yaitu ruang kelas yang kurang memadai. Ada beberapa strategi kepala sekolah yang dapat dilakukan, yaitu (1) mengundang orang tua peserta didik untuk datang ke sekolah tujuannya untuk melakukan sosialisasi (menjelaskan permasalahan yang ada di sekolah mengenai kurangnya ruang kelas dan perlunya pemenuhan ruang kelas yang memadai serta rencana untuk pembangunan ruang kelas yang memadai) dan (2) menjalin kemitraan dengan industri atau perusahaan swasta.

\section{Saran}

Berdasarkan permasalahan yang terjadi atau dialami oleh SMK Graha Singosari, ada beberapa strategi kepala sekolah yang dapat dilakukan untuk meningkatkan kualitas sekolah melalui pemenuhan ruang kelas yang memadai, yaitu (1) mengundang orang tua peserta didik untuk datang ke sekolah tujuannya untuk melakukan sosialisasi (menjelaskan permasalahan yang ada di sekolah mengenai kurangnya ruang kelas dan perlunya pemenuhan ruang kelas yang memadai serta rencana untuk pembangunan ruang kelas yang memadai) dan (2) menjalin kemitraan dengan industri atau perusahaan swasta.

\section{DAFTAR RUJUKAN}

Alimi. (2012). School Types, Facilities and Academic Performance of Students in Senior Secondary Schools in Ondo State, Nigeria. Journal International Education Studies, 5(3), 44-48.

Cahyana, A. (2010). Upaya Peningkatan Mutu Sekolah melalui Satuan Otonomi Pendidikan. Jurnal Pendidikan Dan Kebudayaan, 16(2), 109.

https://doi.org/10.24832/jpnk.v16i2.43
7

Darmastuti, H., \& Karwanto. (2014). Kualitas Pembelajaran Pada Jurusan Teknik Komputer Dan Informatika Di SMK Negeri 2 Surabaya. Jurnal Inspirasi Manajemen Pendidikan, 3(3), 9-20.

Ekosiswoyo, R. (2007). Kepemimpinan Kepala Sekolah yang Efektif Kunci Pencapaian Kualitas Pendidikan. Jurnal IImu Pendidikan, 14(2), 76-82. https://doi.org/10.17977/jip.v14i2.24

Fasasi, \& Oyeniran. (2014). Assessing Principals' Quality Assurance Strategies in Osun State Secondary Schools, Nigeria. Journal International of Instruction, 7(1), 165176.

Muh. Fitrah. (2017). Peran Kepala Sekolah Dalam Meningkatkan Mutu Pendidikan. Jurnal Penjaminan Mutu, 3(1), 31-42.

Patterson. (2008). What Makes A Teacher Effective? Childhood Education. Buckinghamshire: Olney.

Sugiyono. (2010). Metode Penelitian Pendidikan Pendekatan Kuantitatif, Kualitatif dan R\&D. Bandung: Alfabeta.

Suhardan, D. (2010). Supervisi Profesional (Layanan Dalam Meningkatkan Mutu Pembelajaran Di Era Otonomi Daerah). Bandung: Alfabeta.

Wang. (2018). School Principals' Job Satisfaction: The Effects of Work Intensification. Journal of Educational Administration and Policy, 1(1), 7390.

Xaba. (2012). A Qualitative Analysis of Facilities Maintenance - A School Governance Function in South Africa. Journal Education, 32(2), 215-226. 